\title{
Socio-economic and Institutional Determinants of Watermelon Marketing in Enugu State Nigeria
}

\author{
Ukwuaba, Ikenna Charles \\ Department of Agricultural Economics \\ University of Nigeria, Nsukka, Enugu, Nigeria \\ E-mail: ikenna.ukwuaba@unn.edu.ng, ukwuabaikenna@gmail.com \\ Phone: +2347030362033
}

\section{Agbo, Festus Ugwuoke}

Department of Agricultural Economics

Michael Okpara University of Agriculture, Umudike, Abia, Nigeria

E-mail: fuagbo4real@yahoo.com

Phone: +2348066592181

\section{Adeosun, Kehinde Paul}

Department of Agricultural Economics

University of Nigeria, Nsukka, Enugu, Nigeria

E-mail: paul.adeosun@unn.edu.ng

Phone: +2348067359255

\section{Abstract}

The study analysed the socio-economic and institutional determinants of watermelon marketing in Enugu state, Nigeria. The specific objectives were to: describe the socio-economic characteristics of watermelon marketers (wholesalers and retailers) and determine the factors influencing the net marketing returns of the marketers. Multistage sampling technique was employed in selecting eight watermelon markets based on the volume of watermelon traded in the markets. Primary data were collected from 160 watermelon marketers comprising 96 retailers and 64 wholesalers with the aid of well-structured questionnaire. Data collected were analysed using descriptive statistics and multiple regression model. Results showed that watermelon marketing was dominated by the married (76.25\%), literates (97.5\%) and females (78.13\%) with the mean age and marketing experience of 47 and seven years respectively. The result from regression shows that product price (0.581) and transportation cost (-2.609) were statistically and significantly influenced wholesalers' net marketing income, while product price (1.501), educational level (-0.584), storage cost (-0.131), packaging cost ($0.077)$ and market information (0.057) were statistically and significantly influenced retailer's net marketing income. There exist potentials in watermelon marketing contributing positively to poverty alleviation, hence, there is need as for market intermediaries to improve their technical knowledge and skills in marketing of watermelon and other perishables through training; this is to ensure that the marketing system becomes more responsive to consumers' demand.

Keywords: Socio-economic, institutional factors, watermelon, marketers, Enugu State 
Creative commons User License: CC BY-NC-ND

Abstracted by: EBSCOhost, Electronic Journals Service (EJS), Google Scholar, Journal Seek, Scientific Commons,

Food and Agricultural Organization (FAO), CABI and Scopus
Journal of Agricultural Extension

Vol. 22 (3) October, 2018

ISSN(e): 24086851; ISSN(Print); 1119944X

http://journal.aesonnigeria.org

http://www.ajol.info/index.php/iae

Email: editorinchief@aesonnigeria.org

\section{Introduction}

The importance of the socioeconomic and institutional factors in the production and marketing of agricultural products cannot be over emphasized. Such factors like access to credit, access to market information, as well as the sex, age, farming or marketing experience and income of the farmers are pivotal to the overall efficiency or otherwise in the agricultural sector, especially in vegetable production and marketing.

Watermelon (Citrullus lanatus) is one of the world's most important vegetables, grown both for its fruit and the vegetative parts which are highly nutritious (Schippers, 2000). It belongs to the cucurbit family commonly known as Cucurbitaceae; it is an important horticultural crop, often known for its sweet and juicy fruit, grown commercially in areas with long frost-free warm climates all over the world (Prohens \& Nuez, 2008). Watermelon global consumption is greater than that of any other cucurbit (Paris, 2016) China is the leading producer of watermelon in the world; it provides one third of the total watermelons in the world, followed by Iran, Turkey, Brazil, Egypt, United States, Uzekistan, Algeria, Russia and Vietnam completes the top ten producers in the world (FAOSTAT, 2017).

Ajewole (2015) reported that watermelon is highly relished as a fresh fruit worldwide due to its thirst-quenching attribute in addition to many other identified nutritional benefits. According to Oguntola (2006), watermelon is the most preferred among five other exotic vegetables such as cantaloupe, squash, cucumber and pumpkin examined in Ibadan Metropolis of Oyo State, Nigeria. The consumption of the commodity in the recent times has witnessed remarkable development as it cuts across all socio economic classes. It's potentials as a cash generating crop is significant for farmers as well as marketers especially those residing near the urban areas. Isibor and Ugwumba (2014) indicated that exotic vegetables production generally generate higher profit, provide more employment and income to the farmers than those of indigenous vegetables. Trevor (2008), in his study in Northern Ghana also noted that watermelon serves as an important source of revenue to farmers and marketers especially in times of unfavourable weather conditions since it is able to withstand harsh weather conditions as compared to other crops.

In Nigeria; watermelon is regarded as a minor crop, compared to other food and cash crops and thus, has attracted very insignificant marketing research attention. Nevertheless, watermelon reaches consumers through the marketing system. Marketing is concerned with all activities, which facilitate the movement of the commodities from the farms to the consumers. Therefore, increase in marketing activity of watermelon would enhance the provision of more and better produce at low price to increased number of consumers which would enable marketers to generate more income and increase welfare. Watermelon marketing has a large potential to enhance agribusiness development, generate income and employment opportunities that will lead to significant impact in the rural sector particularly for households in the minor producing areas like Enugu State. More so, watermelon marketing in Enugu State, Nigeria is an intervention strategy for the poor to earn extra income and source of livelihood especially for those living in peri-urban areas. Several studies have been conducted with respect to watermelon production in Africa; some focused on the 
Creative commons User License: CC BY-NC-ND

Abstracted by: EBSCOhost, Electronic Journals Service (EJS), Google Scholar, Journal Seek, Scientific Commons,

Food and Agricultural Organization (FAO), CABI and Scopus
Journal of Agricultural Extension

Vol. 22 (3) October, 2018

ISSN(e): 24086851; ISSN(Print); 1119944X

http://journal.aesonnigeria.org

http://www.aiol.info/index.phpliae

Email: editorinchief@aesonnigeria.org

economic analysis of its production system (Adeoye et al., 2011), income and factor analysis of watermelon (Oladele, 2015), traditional knowledge with respect to the cultivation and uses of watermelon in Mozambique (Munisse, Andersen, Jensen \& Christiansen, 2011). Though Onyemauwa (2010), Kainga (2013), Isibor \& Ugwumba (2014) and Olumide (2015) concentrated on the marketing margins and marketing efficiencies of watermelon in their studies in urban areas of South-West and SouthSouth of Nigeria, available literatures showed that limited researches were conducted along the key socio-economic and institutional factors that determine the level of net marketing income of watermelon in Enugu State, Nigeria.

There is considerable variability in watermelon prices within the year due mostly to seasonal changes in the volume of production as it is mostly rain fed. The distribution and availability of exotic vegetables, including watermelon in the South eastern part of Nigeria tends to be inadequate and inefficient (Osondu, Nwadike, Ijioma, Udah, \& Ugboaja, 2014). The product is rarely produced in Enugu State and its external influx could pose high cost of marketing on the product and implicitly the price of watermelon very exorbitant. In view of the rising demand for watermelon in the study area amidst inefficient marketing (FAO, 1997), therefore, it is pertinent and relevant to analyse the key determinants of the watermelon marketing in Enugu State, Nigeria. The study specifically sought to describe the socio-economic characteristics of watermelon marketers and determine the factors influencing net income of watermelon marketing.

\section{Methodology}

The study was conducted in Enugu State, Nigeria. Enugu State is one of the 36 States in Nigeria, located at the Southeast geopolitical zone of the country. It lies between latitudes $5^{0} 56^{\prime} \mathrm{N}$ and $7^{0} 05^{\prime} \mathrm{N}$ of the Equator and longitudes $6^{0} 53^{\prime} \mathrm{E}$ and $7^{0} 55^{\prime} \mathrm{E}$ of the Greenwich meridian (Enugu State Agricultural Development Programme [ENADEP], 2009). Enugu State shares boundaries in the East with Ebonyi State, in the North with Benue and Kogi States, in the South with Abia State and in the West with Anambra State. The State occupies a land mass of approximately $8,022.95 \mathrm{~km}^{2}$ with a population of about 3,257,298 (National Population Comission (NPC), 2006; ENADEP, 2012). It has a tropical climate and experiences distinct wet and dry seasons with a total annual rainfall of about 1,700mm (Enugu State Government Official Gazette, 1997). The rainy season starts from April to October and dry season from November to March (Okorie, 2012).

Farming is the major occupation of the people in the rural areas while trading and civil service dominate the economic activities in the urban areas. The people are warm highly enterprising and could be found engaged in trade all over the country; mostly engaged in small scale farming and marketing of many agricultural produces. It has several markets both in the rural and urban areas where agricultural goods are sold. The state consists of 17 Local Government Areas (LGAs) and it is divided into six agricultural zones (AZs) (ENADEP, 2012). 
Multi-stage sampling technique was employed in selection of respondents for this study. The first stage involved a purposive selection of four AZs (Enugu, Nsukka, Agbani and Enugu Ezike) from the six AZs in the State. This was done so as to select AZs with substantial volume of watermelon markets. In stage two, one extension block was purposively selected from each of the four AZs, giving a total of four extension blocks The selection was based on the concentration of vegetables and fruits markets in the extension blocks. Stage three also involved a purposive selection of two markets where watermelons are sold in relatively large quantities in the extension blocks selected, this gave a total of eight markets (New Relief market, Ogbete market, Orie Orba, Obollo Afor market, Ikpa commodity market, Ogige market, Eke Agbani and Orie Awgu). Subsequently, from each of the selected watermelon markets, having obtained the sampling frame, $50 \%$ of watermelon marketers were randomly selected in each market to give a total sample size of 160 marketers, consisting of 64 wholesalers and 96 retailers.

Primary data were used for the study. The primary data were collected using a set of semi-structured and pre-tested questionnaire. The questionnaires were administered to the respondents with the help of research assistant familiar with the selected markets. The data for this study were analyzed using descriptive and multiple regression models.

The Ordinary Least Square was explicitly specified as:

$Y=\beta_{0}+\beta_{1} X_{1+} \beta_{2} X_{2}+\beta_{3} X_{3}+\beta_{4} X_{4}+\beta_{5} X_{5}+\beta_{6} X_{6}+\beta_{7} X_{7}+\beta_{8} X_{8}+\beta_{9} X_{9+}, \beta_{10} X_{10+} e$

Where:

$Y=$ Net Returns from watermelon marketing (Naira)

$\beta_{0}=$ intercept of $Y$

$X_{1}=$ Number of years spent in School (years)

$X_{2}=$ Marketing experience (number of years in watermelon marketing)

$X_{3}=$ Cost of produce (Naira)

$\mathrm{X}_{4}=$ Transport cost (Naira)

$\mathrm{X}_{5}=$ Storage cost (Naira)

$X_{6}=$ Packaging cost (Naira)

$\mathrm{X}_{7}=$ Handling cost (Naira)

$X_{8}=$ Access to Market information (access $=1$, otherwise 0 )

$X_{9}=$ Access to credit (access $=1$, otherwise 0 )

$X_{10}=$ Market Association (membership $=1$, otherwise 0 )

$\mathrm{e}=$ Error term or random disturbance

The four functional forms of the model were fitted with the data. The lead equation was selected based on statistical and econometric criteria including number of significant variables, magnitude of the F-ratio and R-squared (coefficient of multiple determinations) estimates and the standard error as well as consistency with the $a$ priori expectations.

\section{Linear function}

$Y=\beta_{0}+\beta_{1} X_{1}+\beta_{2} X_{2}+\beta_{3} X_{3}+\beta_{4} X_{4}+\beta_{5} X_{5}+\beta_{6} X_{6}+\beta_{7} X_{7}+\beta_{8} X_{8}+\beta_{9} X_{9}+\beta_{10} X_{10}+e$

Semi-log function

$Y=\beta_{0}+\beta_{1} \log X_{1}+\beta_{2} \log X_{2}+\beta_{3} \log X_{3}+\beta_{4} \log X_{4}+\beta_{5} \log X_{5}+\beta_{6} \log X_{6}+\beta_{7} \log X \beta$

$\beta_{8} \log X_{8}+\beta_{9} \log X_{9}+\beta_{10} \log X_{10}+e$

Double-log function

$\log Y=\beta_{0}+\beta_{1} \log X_{1}+\beta_{2} \log X_{2}+\beta_{3} \log X_{3}+\beta_{4} \log X_{4}+\beta_{5} \log X_{5}+\beta_{6} \log X_{6}+\beta_{7} \log X_{7}+$ 
$\beta_{8} \log X_{8}+\beta_{9} \log X_{9}+\beta_{10} \log X_{10}+e$

Exponential function

$Y=\beta_{0}+\beta_{1} X_{1}+\beta_{2} X_{2}{ }^{2}+\beta_{2} X_{3}{ }^{3}+\beta_{4} X_{4}{ }^{4}+b_{5} X_{5}{ }^{5}+\beta_{6} X_{6}{ }^{6}+\beta_{7} X_{7}{ }^{7}+\beta_{8} X_{8}{ }^{8}+\beta_{9} X_{9}{ }^{9}+\beta_{10} X_{10}{ }^{10}+e$

\section{Results and Discussion}

\section{Socio-economic Characteristics of the Watermelon Marketers}

The distributions of marketers according to socio-economic characteristics are presented in Table 1 . The Table shows that $51.6 \%$ of wholesalers were males while $97.9 \%$ of the retailers were females. This implied that males slightly dominated the wholesale level of the market while the females dominated the retail level. The result could be as a result of few females being willing to take the risks of long distance trips, theft, transportation stress. The result is in agreement with Isibor and Ugwumba (2014) who reported that males dominated the wholesale market level, while females dominated the retail level of watermelon in Nnewi metropolis, Anambra State.

However, the result contradicted the finding by Agbugba (2014) who reported that marketing of vegetables at wholesale level were dominated by females in Enugu State. Table 1 also showed that about $44.38 \%$ of the marketers were within the age range of 41 to 50 years. The mean age of the wholesalers was 50 years and that of the retailers was 44 years, implying that typical marketers of watermelon in the area were in the economically active age group. The results indicate that the marketers were young and energetic and are able to deal with the exigencies of travels; thus can bear the stress and take the risks involved in the enterprise especially at the wholesale level. The majority of the wholesalers $(90.6 \%)$ and retailers $(66.7 \%)$ were married. Ani (2015) opined that marriage has a direct relationship with family stability; therefore, the high percentages of married respondents suggest that the watermelon marketers are stable and able to make good business decisions. 
Creative commons User License: CC BY-NC-ND

Abstracted by: EBSCOhost, Electronic Journals Service (EJS), Google Scholar, Journal Seek, Scientific Commons,

Food and Agricultural Organization (FAO), CABI and Scopus
Journal of Agricultural Extension

Vol. 22 (3) October, 2018

ISSN(e): 24086851; ISSN(Print); 1119944X

http://journal.aesonnigeria.org

http://www.ajol.info/index.php/iae

Email: editorinchief@aesonnigeria.org

Table 1: Socio-economic characteristics of watermelon marketers

\begin{tabular}{|c|c|c|c|}
\hline \multirow{2}{*}{ Variables } & \multirow{2}{*}{$\begin{array}{l}\text { Wholesalers } \\
\text { Percentage }(n=64)\end{array}$} & \multirow{2}{*}{$\begin{array}{l}\text { Retailers } \\
\text { Percentage }(\mathrm{n}=96)\end{array}$} & \multirow{2}{*}{$\begin{array}{l}\text { Total Mark } \\
\text { Percentage }(n=160)\end{array}$} \\
\hline & & & \\
\hline \multicolumn{4}{|l|}{ Sex } \\
\hline Male & 51.6 & 2.1 & 21.89 \\
\hline Female & 48.4 & 97.9 & 78.13 \\
\hline \multicolumn{4}{|l|}{ Age (years) } \\
\hline$\leq 20$ & - & 3.1 & 1.88 \\
\hline $21-30$ & 1.6 & 16.7 & 10.63 \\
\hline $31-40$ & 3.1 & 13.5 & 9.38 \\
\hline $41-50$ & 56.2 & 36.5 & 44.38 \\
\hline $51 \&>$ & 39.1 & 30.2 & 33.75 \\
\hline Mean & 50.02 & 43.83 & 46.7 \\
\hline \multicolumn{4}{|l|}{ Marital status } \\
\hline Married & 90.6 & 66.7 & 76.5 \\
\hline Single & 1.6 & 26.0 & 16.25 \\
\hline Widowed & 7.8 & 7.3 & 7.50 \\
\hline \multicolumn{4}{|l|}{ Household size } \\
\hline $1-3$ & 6.2 & 22.9 & 16.25 \\
\hline $4-6$ & 45.3 & 43.8 & 44.38 \\
\hline $7-9$ & 45.3 & 30.2 & 36.25 \\
\hline $10-11$ & 3.1 & 3.1 & 31.88 \\
\hline Mean & 6.16 & 5.44 & 5.8 \\
\hline \multicolumn{4}{|l|}{ Educational status } \\
\hline No formal education & - & 4.2 & 2.50 \\
\hline Primary education & 40.6 & 41.7 & 41.25 \\
\hline Secondary school & 46.9 & 49.0 & 48.13 \\
\hline Tertiary & 12.5 & 5.2 & 8.13 \\
\hline \multicolumn{4}{|l|}{ Marketing } \\
\hline \multicolumn{4}{|l|}{ Experience (years) } \\
\hline $2-4$ & 15.6 & 32.3 & 25.63 \\
\hline $5-7$ & 50.0 & 42.7 & 45.63 \\
\hline $8-10$ & 25.0 & 16.7 & 20 \\
\hline $11-13$ & 1.6 & 4.2 & 3.13 \\
\hline $14-16$ & 7.8 & 4.2 & 5.63 \\
\hline Mean & 7.05 & 6.11 & 6.58 \\
\hline \multicolumn{4}{|l|}{ Major Occupation } \\
\hline Farming & - & 5.2 & 3.13 \\
\hline Civil Service & 6.2 & 5.2 & 5.63 \\
\hline Trading & 93.8 & 74.0 & 81.88 \\
\hline Student & - & 15.6 & 9.38 \\
\hline
\end{tabular}

\section{Source: Field Survey, 2017}

The mean household size of the wholesalers and retailers were six and five members, respectively. This implies that the two categories of marketers had available labour force to assist them in their respective businesses. The result was in consonance with the mean household size of six persons reported by Obetta, (2015) in a study of banana and plantain marketing in Enugu State. However, Osondu and ljeoma (2015) reported that large household size could limit the net returns from marketing due to the diversion of potential investment funds as a result of increased household consumption expenses. Results on the educational status of the marketers showed 
that $40.9 \%$ and $41.7 \%$ of the wholesalers and retailers, respectively had primary school education, while $46.9 \%$ and $49 \%$ of the wholesalers and retailers respectively had secondary school education only. The result indicated that the marketers are literate, an advantage which according to FAO (2006), could translate to higher business acumen in terms of level of profit. The result corroborates the finding of Ani (2015) who reported a similar educational status in Enugu State among soybeans marketers. $50 \%$

The majority of the wholesalers and retailers (42.7\%) had between five to seven years marketing experience. The mean years of marketing experience for wholesalers and retailers were seven and six respectively. This implied that most of the respondents were new entrants and watermelon marketing is a new and growing enterprise. Chukwuji (2006) noted that success and stability of any business depends on the skill and experience of the manager, while Ugwumba (2010) and ljeoma (2012) opined that education and experience are veritable tools for acquiring new ideas and skills that reflect positively on scope of enterprising, income and profit. The majority of the $(93 \%)$ wholesalers and retailers $(74 \%)$ were full time traders. Results indicate that about $15.6 \%$ of retailers were students, while farmers and civil servants accounted for $5 \%$ each as retailers. The fact that the majority of the wholesalers were full time traders could be attributed to the tedious and stressful nature of the business especially at the wholesale level. This could be attributed to the fact that the majority of the watermelon marketed in the study area was purchased from Northern part of Nigeria.

\section{Determinants of Net Marketing Income of Watermelon Wholesalers}

The multiple regression estimates of factors influencing the net marketing income of watermelon wholesalers are presented in Table 2. The results show that $52 \%$ of the variations in the net marketing returns were explained by the variations in the independent variables. It also showed that cost of produce and transportation cost were statistically significant variables and thus exerted influence on wholesalers' net marketing returns. This implied that they were among the major determinants of marketers' net income in the study area.

The coefficient of cost of watermelon was positive (1.15) and statistically significant at $5 \%$ level of probability, indicating that the higher the cost of watermelon, the higher the net marketing returns of the wholesalers and vice versa. The result is in agreement with the findings of Onyemauwa (2010) and Kainga (2013) who reported a positive and significant effect of cost of watermelon on the net marketing returns. The result is also consistent with the finding of Osondu et al. (2014) in the determinants of net marketing returns of Cabbage in Abia State. Conversely, transportation cost was negative (-2.60) and statistically significant at $5 \%$ level of probability. The negative sign associated with the variable indicates an inverse relationship with the net marketing returns. This implies that a unit increase in transportation decreased the income of the wholesaler by 2.60 units as shown in Table 2. 
Creative commons User License: CC BY-NC-ND

Abstracted by: EBSCOhost, Electronic Journals Service (EJS),

Google Scholar, Journal Seek, Scientific Commons,

Food and Agricultural Organization (FAO), CABI and Scopus
Journal of Agricultural Extension

Vol. 22 (3) October, 2018

ISSN(e): 24086851; ISSN(Print); 1119944X

http://journal.aesonnigeria.org

http://www.ajol.info/index.php/iae

Email: editorinchief@aesonnigeria.org

Table 2: Regression result showing the factors influencing net marketing income of watermelon for wholesalers

\begin{tabular}{|c|c|c|c|c|}
\hline Variables & Linear ++ & Semi- Log & $\begin{array}{l}\text { Double } \\
\text { Log }\end{array}$ & Exponential \\
\hline Constant & $\begin{array}{c}-876040.6 \\
(-0.64)\end{array}$ & $\begin{array}{c}5.429553 \\
(12.56)\end{array}$ & $\begin{array}{c}0.5711547 \\
(0.17)\end{array}$ & $\begin{array}{c}964386.3 \\
(2.32)\end{array}$ \\
\hline Educational level & $\begin{array}{c}2722.978 \\
(0.06)\end{array}$ & $\begin{array}{c}0.002304 \\
(0.46)\end{array}$ & $\begin{array}{c}0.1502004 \\
(0.46)\end{array}$ & $\begin{array}{c}26300.91 \\
(0.64)\end{array}$ \\
\hline $\begin{array}{l}\text { Marketing } \\
\text { Experience }\end{array}$ & $\begin{array}{c}14238.43 \\
(0.39)\end{array}$ & $\begin{array}{c}0.0052675 \\
(0.45)\end{array}$ & $\begin{array}{c}0.1424239 \\
(0.69)\end{array}$ & $\begin{array}{c}1330.893 \\
(0.70)\end{array}$ \\
\hline Cost of watermelon & $\begin{array}{l}1.151256^{* *} \\
(2.28)\end{array}$ & $\begin{array}{c}1.47 \mathrm{E}-07 \\
(1.41)\end{array}$ & $\begin{array}{c}0.947282 \\
(1.46)\end{array}$ & $\begin{array}{c}-1.71 \mathrm{E}-15 \\
(-0.14)\end{array}$ \\
\hline Transportation cost & $\begin{array}{c}-2.609858^{\star *} \\
(-2.10)\end{array}$ & $\begin{array}{c}-1.00 \mathrm{E}-06^{* *} \\
(-2.53)\end{array}$ & $\begin{array}{c}-1.136455 \\
(-1.88)\end{array}$ & $\begin{array}{c}-1.35 \mathrm{E}-18^{\star *} \\
(-2.14)\end{array}$ \\
\hline Storage cost & $\begin{array}{c}-46.9208 \\
(-1.32)\end{array}$ & $\begin{array}{c}-0.0000161 \\
(-1.42)\end{array}$ & $\begin{array}{c}-0.1450067 \\
(-1.39)\end{array}$ & $\begin{array}{c}-8.58 \mathrm{E}-15 \\
(-1.18)\end{array}$ \\
\hline Handling cost & $\begin{array}{c}114.6615 \\
(1.28)\end{array}$ & $\begin{array}{c}0.000428 \\
(1.50)\end{array}$ & $\begin{array}{c}1.466591 \\
(0.87)\end{array}$ & $\begin{array}{c}3.61 \mathrm{E}-21^{* *} \\
(2.15)\end{array}$ \\
\hline Market information & $\begin{array}{c}-26271.42 \\
(320102.6)\end{array}$ & $\begin{array}{c}-0.007757 \\
(-0.08)\end{array}$ & $\begin{array}{c}-0.0388155 \\
(0.0995)\end{array}$ & $\begin{array}{c}-454485.66 \\
(-0.14)\end{array}$ \\
\hline Formal credit & $\begin{array}{c}310745.9 \\
(1.13)\end{array}$ & $\begin{array}{c}0.1045023 \\
(1.19)\end{array}$ & $\begin{array}{c}0.0865954 \\
(1.01)\end{array}$ & $\begin{array}{c}379014.7 \\
(1.30)\end{array}$ \\
\hline Market association & $\begin{array}{c}-145236.2 \\
(-0.47)\end{array}$ & $\begin{array}{c}-0.0425023 \\
(-0.80)\end{array}$ & $\begin{array}{c}-0.0459539 \\
(-0.36)\end{array}$ & $\begin{array}{c}-93144.27 \\
(-0.54)\end{array}$ \\
\hline$R^{2}$ & 0.523 & 0.388 & 0.392 & 0.487 \\
\hline Adjusted $\mathrm{R}^{2}$ & 0.432 & 0.272 & 0.277 & 0.393 \\
\hline F- Ratio & 5.79 & 3.36 & 3.42 & 5.09 \\
\hline
\end{tabular}

${ }^{* *}$, denote significance at $5 \%$ Probabililty level

Figures in parentheses are t-values ${ }^{++}$: Lead equation

Source: Field Survey, 2017

\section{Determinants of Net Marketing Income of Watermelon Retailers}

The result shows that $98 \%$ of the variations in the net marketing returns of the retailers were explained by the variations in the independent variables. The result in Table 3 indicates that educational level, packaging cost, storage cost, cost of produce and market information affected the net marketing income of the retailers in the study area. Educational level attained was negative $(-0.63)$ and statistically significant at $5 \%$ level of probability. The result implied that a unit increase in the educational level of the retailers decreased the net marketing income by 0.63 units. 
Creative commons User License: CC BY-NC-ND

Abstracted by: EBSCOhost, Electronic Journals Service (EJS), Google Scholar, Journal Seek, Scientific Commons,

Food and Agricultural Organization (FAO), CABI and Scopus
Journal of Agricultural Extension

Vol. 22 (3) October, 2018

ISSN(e): 24086851; ISSN(Print); 1119944X

http://journal.aesonnigeria.org

http://www.ajol.info/index.php/iae

Email: editorinchief@aesonnigeria.org

Tables 3: Regression result showing the factors influencing net marketing income of watermelon for retailers

\begin{tabular}{|c|c|c|c|c|}
\hline Variables & Linear & Semi- Log & Double Log ${ }^{++}$ & Exponential \\
\hline Constant & $\begin{array}{c}1200.364 \\
(0.23)\end{array}$ & $\begin{array}{c}3.786765 \\
(54.32)\end{array}$ & $\begin{array}{c}-2.175516 \\
(-14.45)\end{array}$ & $\begin{array}{c}22264.45 \\
(5.77)\end{array}$ \\
\hline Educational level & $\begin{array}{c}-132.0308 \\
(-0.44)\end{array}$ & $\begin{array}{c}-0.0068396 \\
(-1.70)\end{array}$ & $\begin{array}{c}-0.629421^{* *} \\
(-3.756)\end{array}$ & $\begin{array}{c}-556.4781 \\
(-1.73)\end{array}$ \\
\hline Marketing & $-938.8823^{* *}$ & 0.0067432 & -0.0037787 & -40.42709 \\
\hline Experience & $(-2.54)$ & (1.31) & $(-0.12)$ & $(-1.66)$ \\
\hline Cost of watermelon & $\begin{array}{c}0.3720588^{* *} \\
(7.54)\end{array}$ & $\begin{array}{c}6.24 \mathrm{E}-06^{* *} \\
(9.29)\end{array}$ & $\begin{array}{c}1.500678^{* *} \\
(25.31)\end{array}$ & $\begin{array}{c}1.07 \mathrm{E}-11^{* *} \\
(10.99)\end{array}$ \\
\hline Transportation cost & $\begin{array}{c}-1.078308 \\
(-0.86)\end{array}$ & $\begin{array}{c}-4.70 \mathrm{E}-06 \\
(-0.28)\end{array}$ & $\begin{array}{c}-0.403419 \\
(-1.34)\end{array}$ & $\begin{array}{c}-7.37 \mathrm{E}-12 \\
(-0.87)\end{array}$ \\
\hline Storage cost & $\begin{array}{c}-1.769488 \\
(-1.70)\end{array}$ & $\begin{array}{c}-0.000040^{* *} \\
(-2.89)\end{array}$ & $\begin{array}{c}-0.1307497^{\star *} \\
(-6.90)\end{array}$ & $\begin{array}{c}-1.10 \mathrm{E}-16 \\
(-0.01)\end{array}$ \\
\hline Packaging cost & $\begin{array}{c}1.759902 \\
(0.77)\end{array}$ & $\begin{array}{c}-3.11 \mathrm{E}-06 \\
(-0.10)\end{array}$ & $\begin{array}{c}-1.1120245^{\star *} \\
(-2.64)\end{array}$ & $\begin{array}{c}-2.57 \mathrm{E}-17 \\
(-1.90)\end{array}$ \\
\hline Handling cost & $\begin{array}{c}2.037569 \\
(0.83)\end{array}$ & $\begin{array}{c}-0.0000106 \\
(-0.32)\end{array}$ & $\begin{array}{c}-0.0203562 \\
(-0.63)\end{array}$ & $\begin{array}{c}-1.24 \mathrm{E}-20^{* *} \\
(-2.77)\end{array}$ \\
\hline Market information & $\begin{array}{c}-40.92864 \\
(-0.01)\end{array}$ & $\begin{array}{c}0.1332461^{* *} \\
(3.18)\end{array}$ & $\begin{array}{c}0.0574413^{\star *} \\
(3.10)\end{array}$ & $\begin{array}{c}-1699.433 \\
(-0.84)\end{array}$ \\
\hline Formal credit & $\begin{array}{c}-1241.543 \\
(-0.28)\end{array}$ & $\begin{array}{c}-0.0034576 \\
(-0.06)\end{array}$ & $\begin{array}{c}-0.0218774 \\
(-0.84)\end{array}$ & $\begin{array}{c}-143.8888 \\
(-0.03)\end{array}$ \\
\hline Market association & $\begin{array}{c}2824.709 \\
(0.92)\end{array}$ & $\begin{array}{c}0.0277328 \\
(0.67)\end{array}$ & $\begin{array}{c}0.0009056 \\
(0.05)\end{array}$ & $\begin{array}{c}3263.29 \\
(0.88)\end{array}$ \\
\hline $\mathrm{R}^{2}$ & 0.869 & 0.900 & 0.981 & 0.804 \\
\hline Adjusted $\mathrm{R}^{2}$ & 0.852 & 0.887 & 0.978 & 0.781 \\
\hline F- Ratio & 50.88 & 67.97 & 375.85 & 34.95 \\
\hline
\end{tabular}

${ }^{* *}$, denote significance at $5 \%$ Probability level

Figures in parenthesis are t-values ${ }^{++}$: Lead equation

Source: Field Survey, 2017

The result could be attributed to the fact that little or no special skills were required in the marketing of watermelon. It could also be that as one becomes more educated, the attention and seriousness given to the watermelon enterprise would reduce, thereby leading to loss of customers and consequently, reduction in income level from the enterprise. This is justifiable as more educated people are involved in white collar jobs, and thus would pay less attention to the trade. This result disagreed with that of Nwankwo (1999), that the level of educational attainment is likely to affect the degree of one's business alertness and ability to seize business initiatives and advantages, hence increased income. Also, the result contradicts the findings of Agbo and Usoroh (2015) who reported that education is positively related to the net market income of shrimp marketers in Akwaibom State, Nigeria.

Packaging costs had a negative $(-1.11)$ effect on retailers' income and was statistically significant at $5 \%$ probability level. The sign implied that the greater the 
packaging cost in the marketing process, the less the net marketing income and viceversa.

Table 3 shows that the storage cost was negative $(-0.13)$ and statistically significant at $1 \%$ level of probability. The result implied that as the storage cost increased the net marketing returns of the retailers decreased and vice versa. The result corroborates the findings by Kainga (2013) who reported a negative relationship between net marketing income and storage cost. However, the result contradicts the findings of Osondu et al. (2014) who found a positive influence of storage cost on the net marketing returns of cabbage marketers in Abia State.

Conversely, cost of produce and market information were positive and statistically significant at $5 \%$ probability level. The sign of the variables implied that significant to the net marketing income of the retailers. Cost of produce (1.50) was increased, the net marketing income of the retailers increased. Market information was statistically significant at $1 \%$ level of probability. The positive sign indicates that an increase in market information increased the net marketing income of the retailers by 0.05 . Marketers with adequate market information tend to be knowledgeable, flexible and easily make good marketing decisions that enhanced the net marketing income.

\section{Conclusion and Recommendation}

There exist potentials in watermelon marketing contributing positively to poverty alleviation especially in this period of economic recession in Nigeria. The net marketing income of watermelon was driven by the cost of produce, transportation cost, packaging cost, storage cost, market information as well as the educational status of the marketers. There is need as for market intermediaries to improve their technical knowledge and skills in marketing of watermelon and other perishables through training; this is to ensure that the marketing system becomes more responsive to consumers' demand.

\section{References}

Adakaren, B., Ahmadu, J., \& Chidebelu, S. (2012). Marketing margin and spatial pricing efficiency of palm oil in Edo state, Nigeria: Implication for food security. In International Agricultural Conference “ANSU AAC 2012” (pp. 191-198).

Adeoye, I., Usman, J., \& Badmus, M. (2011). Economic Analysis of Watermelon Based Production System in Oyo State, Nigeria. Journal of Applied Science and Environmental Management, 6(7), 53-59.

Agbo, F.U., \& Usoroh, B. A. (2015). Marketing of estruine shrimps in Awka lbom State, Nigeria. Journal of Marketing and Consumer Research, 15(7), 63-70.

Agbugba, I. K. (2014). Marketing of dry season vegetables in South-East Nigeria. A Ph.D Thesis

Ajewole, O. C. (2015). Income and factor analysis of watermelon production in Ekiti State, Nigeria. Journal of Economics and Sustainable Development, 6(2), 67-73.

Ajewole, O. C., \& Folayan, J. (2008). Stochastic frontier analysis of technical efficiency in dry season leaf vegetable production among smallholders in Ekiti 


\section{State, Nigeria. Agricultural}

Ani, D.P. (2015). Market Integration and Pricing efficiency of soyabeans in Benue and Enugu States, Nigeria. A Ph.D Thesis submitted to the Department of Agricultral Economics, University of Nigera, Nsukka.

Busari, A.O., Idris-Adeniyi, K.M., \& Oyekale, J.O. (2012). Economic Analysis of Vegetable Production by Rural Women in Iwo zone of Osun State, Nigeria. Greener Journal of Agricultural Sciences, 3(1), 006-011.

Bosede, I., Olubunmi, A., \& Balogun, L. (2012). Consumer preference for watermelon varieties in urban environment of Ibadan metropolis, Oyo State, Nigeria. Food Global Science Books, 6(1), 1-4.

Chukwuji, C. (2006). Factor productivity and technical efficiency in cassava based food crop production system in Delta State, Nigeria. An M.Sc Thesis submitted to the Department of Agricultural Economics and Extension, Delta State University, Abraka, Nigeria.

Egbuna, N. (2009). Urban agriculture: A strategy for povertry reduction in Nigeria. Retrieved fromhttp://www.docstoc.com/docs/34548910/URBAN-AGRIC-AS-ASTRATEGY-POVERTY-REDUCTION-IN-NIGERIA

ENADEP. (2012). Enugu State Agricultural Development Programme.

Enugu State Government Official Gazette. (1997). Enugu State Government Official Gazette, Enugu State.

Food and Agricultural Organization of United Naions, (FAO). (1997). Agriculture, food and nutrition for Africa: A Resources Book for Teachers of Agriculture. Rome: United Nations Publications.

Food and Agricultural Organization Statistics Division,(FAO). (2008). Crops. Rome. Retrieved from http://faostat.fao.org/site/567/default.aspx\#ancor

Food and Agriculture Organization of United Nations, (FAO). (2011). Global food losses

Food and Agricultural Organization Statistics Division,(FAO). (2017). Crops and Horticulture. Rome. Retrieved from http://faostat.fao.org/en/\#data/QC/visualize.

Huh, Y. C., Solmaz, I., \& Sari, N. (2008). Morphological characterization of Korean and Turkish watermelon. In IXth EUCARPIA meeting on genetics and breeding of Cucurbitaceae (Pitrat M, ed), INRA, Avignon (France), (pp. 327-334).

ljeoma, J.(2012). Adoption of improved snail production techniques by farmers in Ohafia agricultural zone, Abia State, Nigeria. In Aniebo, A., \& Ugwumba ,C.O.A. (Eds.), (pp. 156- 167.). International Agricultural Conference, ANSUISAC, Nigeria.

Isibor, A., \& Ugwumba, C. O. (2014). Analysis of watermelon (Citrullus lanatus) Marketing in Nnewi Metropolis of Anambra State, Nigeria. Journal of Sciences and Multidisciplinary Research, 6(2), 1-8. 
Kainga, E. P. (2013). Marketing margin and determinants of net return of watermelon marketing in Yenagoa Metropolis of Bayelsa State, Nigeria. Journal of Experimental Biology and Agricultural Sciences, 1(4), 241-247.

Munisse, P., Andersen, S., Jensen, B. D., \& Christiansen, J. (2011). Diversity of landraces, agricultural practices and traditional uses of watermelon(Citrullus Lanatus) in Mozambique. African Journal of Plant Science, 5(2), 75-86.

Nwankwo, H. M. (1999). Impact of community banks in financing agricultural production in Abia State: A case study of umuariaga community bank ikwuano LGA Abia State, Nigeria. A PGD Research Report of College of Agriculture, Abia State University.Uturu

Nya, E. J., Okorie, N. U., \& Eka, M. J. (2010). An economic analysis of (Talinum triangulare) production in Southern Nigeria. Trends in Agricultural Economics3(1),79-93. Retrieved from http//scialert.net/astract/doi=tae.2010.79.93

Oguntola, S. (2006, July). Watermelon, Hidden Gem Yet to be Discovered. Nigeria Tribune, p. 31.

Okonmah, L., Agbogidi, O., \& Nwagu, O. (2011). Evaluation of four varieties of watermelon ( Citrullus lanatus Thumb) in Asaba Agro-Ecological Environment. International Journal of Advanced Biological Research, 1(1), 126-130.

Okorie, O. J. (2012). Level of adoption of improved cassava varieties and the profitability of cassava production in Enugu state, Nigeria. An MS.c Thesis submitted to the Department of Agricultural Economics, University of Nigeria, Nsukka.

Olumide, J. (2015). An appraisal of the structure and conduct of watermelon marketing in Akure metropolis , Ondo State, Nigeria. Sky Journal of Agricultural Research, 4(4), 80-89.

Oladele (2015). Challenges and prospects of agriculture in Nigeria: The way forward. Journal of Economics and Sustainable Development, 4(6), 37-45.

Onyemauwa, C. S. (2010). Marketing margin and efficiency of watermelon marketing in Niger Delta Area of Nigeria, Agricultura Tropica Et Subtropica, 43(3), 196-201.

Osondu, C. K. \& ljioma, J. C. (2014). Analysis of profitability and production determinants of fish farming in capital territory of Abia State, Nigeria. World Journal of Agricultural Sciences, 2 (7): 168-176.

Paris, H.S. (2016). Overview of the origins and history of five major cucurbit crops: issues for ancient DNA analysis of archaeological specimens. Vegetation History and Archaelobotany, 25(4). DOI:10.1007/s00334-016-0555-1

Prophens, J., \& Nuez, F. (2008). Vegetables. In Handbook of Plant Breeding (1st ed., pp. 381-385). Berlin: Springer Press.

Schippers, R. (2000). African indigenous vegetables: An overview of cultivated species. United Kingdom: Natural Resource Institute, University of Greenwich. 
Creative commons User License: CC BY-NC-ND

Abstracted by: EBSCOhost, Electronic Journals Service (EJS),

Google Scholar, Journal Seek, Scientific Commons,

Food and Agricultural Organization (FAO), CABI and Scopus
Journal of Agricultural Extension

Vol. 22 (3) October, 2018

ISSN(e): 24086851; ISSN(Print); 1119944X

http://journal.aesonnigeria.org

http://www.ajol.info/index.php/iae

Email: editorinchief@aesonnigeria.org

Trevor, W. (2008). Too much of Good Thing. Trevorblogspot. Retrieved January 26, 2016, from http://trevoringhana.blogspot.com/2008/02/too-much-of-goodthing.htm.

Ugwumba, C. O. (2010). Analysis of the agribusiness of catfish marketing for poverty alleviation and women empowerment in Anambra, State. In R. Okoh (Ed.), Nigeria Engendering Policy for Attainment of Millennium Development Goals (pp. 89-98.). Asaba, Nigeria: 1st Annual National Conference of Centre for Human Research and Gender Services.

United States Department for Agriculture (USDA). (1998). Empirical studies of the organization and performance of Industries. Rome.

Varmudy, V. (2012). Watermelons: Needs to capture foreign Market. FACTS FOR YOU. http//www.vcputtur.com/../watermelon_Aug 12. pdf. Accesssed online on 04/03/2016. 